INSECT PESTS OF SUGAR HONEY LEAF, Stevia rebaudiana BERTONI AND ASSOCIATED NATURAL ENEMIES IN EGYPT Bazazo, K.G.I.*; Amira Sh. M. Ibrahim ${ }^{\star *}$ and Fathia A. Salem ${ }^{\star \star *}$ *Plant Protection Res. Dept., Sugar Crops Res. Inst., Agric. Res. Center ${ }^{\star *}$ Economic Entomology Dept., Fac. Agric., Kafrelsheikh Univ.

${ }^{\star \star \star * B i o l o g i c a l ~ C o n t r o l ~ R e s . ~ D e p t ., ~ P l a n t ~ P r o t e c t i o n ~ R e s . ~ I n s t ., ~ A g r i c . ~ R e s . ~}$ Center

\begin{abstract}
The current study was carried out during 2010/2011 and 2011/2012 seasons at the Experimental Farm of Sakha Agricultural Research Station for surveying insect pests of Stevia plants and associated with natural enemies, monitoring population size of major insect pests and identify arthropods trapped in spider webs. Data indicated that 20 species of insect pests, belonging to 15 families and 9 orders. 17 species of hymenopterous belonging to ten families. 17 species of predatory insects belonging to 9 families and 6 orders. 16 spider species belonging to ten families (Order: Araneae). The greatest population size in three successive cuts were; Bemisia tabaci (Genn.), Thrips tabaci Lind. and Empoasca spp. webs of some spider families were examined to find out the arthropods trapped inside. It was found that these webs contained 93.48\%insect pests and mites, $6.52 \%$ insect predators and parasitoids. This show that the spider webs captured mainly the harmful arthropods.
\end{abstract}

\title{
INTRODUCTION
}

Sugar honey leaf, Stevia rebaudiana Bertoni (Family: Compositae), is a non-caloric natural-source alternative to artificially produced sugar substitutes. It is used as a sweetener, medicine, cosmetic ingredient, pickling agent, dentifrice, a flavor in cereals, breads, juices, candies, yoghurt and ice cream (Heikal et al., 2008). Phillips (1988) reported that Stevia contains eight glycoside compounds, and Stevioside is the most abundant one. The extracts of these compounds may be up to 300 times sweeter than sugar (Tanaka, 1997). The total market values of Stevia sweetener in Japan is estimated to be around 2-3 billion yen/year (Megeji et al., 2005). The crop has been cultivated allover the world, e.g. Brazil, Korea, Mexico, USA, Indonesia, Tanzania and Canada (Fors, 1995).

Aphids, whiteflies, mites, thrips, mealy bugs and cutworms are the dominant insects in Stevia fields allover the world (Thomas, 2000; Midmore and Rank, 2002 and Anonymous, 2010). Midmore and Rank (2002) reported that insect do not appear to be a problem Stevia has shown clear aphid resistance, the sweet taste being a possible deterrent to insects. Aphids, grasshopper and bugs are the dominant insect pests in Stevia fields (Anonymous, 2004). Megeji et al. (2005) indicated that insects like aphids, whiteflies, mealy bugs and red spider mite were observed in the experimental field, but without much harm to the crop. Fields grown with Stevia are not known to have serious insect pest problems and are often reported as exhibiting insect-repellent qualities (Anonymous, 2010). But, aphids, thrips and white flies can become a serious problem on Stevia in greenhouses, 
which could significantly impact transplant production. Stevia plants are vulnerable hosts to insects and diseases (Anonymous, 2010).

In Egypt, Ministry of Agriculture and Land Reclamation is planning to expand the cultivated Stevia area in the coming decades to reduce imports and, if possible, to achieve self-sufficiency of sugar. The total area cultivated with Stevia reached 5000 feddans sponsored by the private companies such as Stevia International Company for Agricultural and Industrial Projects (Behira) and Glyco Medical Industries.

In Egypt, there are many research papers about the effect of different agricultural practices on quantity and quality of Stevia (Allam et al., 2001; Attia, 2005 and Nassar et al., 2006). But, as the author awares, this is the first investigation about the insects associated with Stevia in Egypt, and this is the first investigation about the natural enemies in allover the world.

The current study was carried out at the Experimental Farm of Sakha Agricultural Research Station during 2010/2011 and 2011/2012 seasons to investigate the following items:

1. Survey insect pests on Stevia plants and their associated insect parasitoids, predators and true spiders.

2. Monitor population size of major insect pests.

3. Identify arthropods (mainly insect pests) trapped in spider webs.

\section{MATERIALS AND METHDOS}

The current investigation was carried out at the Experimental Farm of Sakha Agricultural Research Station during 2010/2011 and 2011/2012 seasons. The experimental Stevia plants field (about $1 / 4$ feddan) was sown with "Spanti" cultivar during the first half of September 2010 until the first half of March 2012. The field received all recommended cultural practices, but without any pesticides used.

\section{Survey of insect pests, and their associated insect parasitoids,} predators and true spiders:

Arthropods were surveyed from September 2010 to March 2012. Weekly examinations were conducted by three methods:

a) Sweep net : (50 double strokes per examination):

Just before sweeping, a cotton piece saturated with chloroform was introduced into the trap to anesthetize the trapped arthropods. After collection, the catch was emptied into glass jars, and transferred to the laboratory for identification.

b) Hand collection (glass test tubes):

Some arthropods, particularly true spiders, were trapped using glass test tubes, as the spiders move quickly away from collecting techniques to hide in the soil, or under plant litters.

c) Visual record: recorded.

Some arthropods, particularly eggs of Chrysoperla, were visually 
2.Monitoring population size of major insect pests:

Major insect pests were monitored from September 2010 to November 2011. Weekly examination were conducted by sweep net (50 double strokes per examination) during three successive cuts.

3.Identify arthropods trapped in spider webs:

Spider spin their webs to capture arthropods for feeding upon. These webs were found to be constructed on the soil and on plants. In each sample, the webs with its contents were carefully picked up using a brush, and introduced into glass vials containing $70 \%$ ethyl alcohol for preservation till identification. Twelve samples ( 15 webs/sample/month) were collected from the beginning of November 2010 up to October 2011.

\section{RESULTS AND DISCUSSION}

1.Survey of insect pests, parasitoids, predators, spiders and monitor population size of major insect pests:

\subsection{Survey insect pests:}

The survey revealed the occurrence of 20 insect species, belonging to 15 families and 9 orders (Table 1). Homoptera was represented by seven species and Lepidoptera was represented by four species, the third rank was that of Orthoptera and Diptera were represented by two species. Collembola, Coleoptera, Hemiptera, Hymenoptera and Thysanoptera were each represented by one species.

Table (1):Survey of insect pests inhabiting Stevia fields at the Experimental Farm of Sakha Agricultural Research Station, during 2010/2011 and 2011/2012 seasons.

\begin{tabular}{|c|c|c|c|}
\hline Order & Family & Genera/species & No. \\
\hline Collembola & Entomobryidae & Lepidocertinus insertus Hand. & 1 \\
\hline Coleoptera & Phalacridae & Unidentified & 1 \\
\hline \multirow[t]{2}{*}{ Diptera } & Agromyzidae & Liriomyza trifolii Backer & \multirow[t]{2}{*}{2} \\
\hline & Tephrittidae & Unidentified & \\
\hline Hemiptera & Pentatomidae & Nezar viridula L. & 1 \\
\hline \multirow{5}{*}{ Homoptera } & Aleyrodidae & Bemisia tabaci (Genn) & 1 \\
\hline & Cicadellidae & $\begin{array}{l}\text { Empoasca lybica de Berg } \\
\text { Empoasca decipiens (Paoli) }\end{array}$ & 2 \\
\hline & Aphididae & $\begin{array}{l}\text { Aphis gossypii (Glover) } \\
\text { Myzus persicae (Sulzer) }\end{array}$ & 2 \\
\hline & Delphacidae & Sogatella sp. & 1 \\
\hline & Pseudococcidae & Planococcus sp. & 1 \\
\hline Hymenoptera & Eurytomidae & Unidentified & 1 \\
\hline Lepidoptera & Noctuidae & $\begin{array}{l}\text { Agrotis ipsilon (Huf.) } \\
\text { Syngrapha circumflexa L. } \\
\text { Phytometra gamma L. } \\
\text { Phytometra ni L. }\end{array}$ & 4 \\
\hline \multirow[t]{2}{*}{ Orthoptera } & Acrididae & Acrida sp. & 1 \\
\hline & Gryllotalpidae & Gryllotalpa gryllotalpa L. & 1 \\
\hline Thysanoptera & Thripidae & Thrips tabaci Lind & 1 \\
\hline Total 9 & 15 & 20 & 20 \\
\hline
\end{tabular}


These results are in agreement with those obtained by many authors in allover the world, e.g. Thomas, 2000, Midmore and Rank, 2002, Anonymous, 2004, Megeji et al., 2005 and Anonymous, 2010.

\subsection{Monitor population size of major insect pests:}

Data presented in Table (2) show the population size of major insect pests inhabiting the three successive Stevia cuts. The greatest population sizes were those of Bemisia tabaci (30.86, 30.31 and 31.28\%), Thrips tabaci (26.23, 21.76 and $20.76 \%$ ), and Empoasca spp. (21.60, 21.76 and $20.51 \%$ ), out of total surveyed insect pests, respectively. Moderate population sizes in three cuts were those of Nezara viridula (7.10, 9.07 and 9.23\%), aphids (6.79, 5.95 and $6.41 \%$ ) and Planococcus sp. (6.17, 7.25 and $6.66 \%$ ), respectively. Low population size were recorded for Collembola $(1.23,3.88$ and $5.12 \%$ ), respectively. Regardless of cuts, the same trend obtained, as $B$. tabaci, T. tabaci and Empoasca spp. were the most occurring while Collembola was the least.

Table (2): Population size of major insect pests attacking Stevia plants in three successive cuts, 2010/2011 and 2011/2012 seasons, using sweep net method.

\begin{tabular}{|c|c|c|c|c|c|c|c|c|}
\hline \multirow{2}{*}{ Insect pests } & \multicolumn{2}{|c|}{$\mathbf{1}^{\text {st }}$ cut } & \multicolumn{2}{c|}{$\mathbf{2}^{\text {nd }}$ cut } & \multicolumn{2}{c|}{$\mathbf{3}^{\text {ra }}$ cut } & \multicolumn{2}{c|}{ Total } \\
\cline { 2 - 9 } & No $^{*}$ & $\%$ & No $^{*}$ & $\%$ & No $^{*}$ & $\%$ & No & $\%$ \\
\hline Bemisia tabaci & 100 & 30.86 & 117 & 30.31 & 122 & 31.28 & 339 & 30.86 \\
\hline Thrips tabaci & 85 & 26.23 & 84 & 21.76 & 81 & 20.76 & 250 & 22.72 \\
\hline Empoasca spp. & 70 & 21.60 & 84 & 21.76 & 80 & 20.51 & 234 & 21.27 \\
\hline Nezara viridula & 23 & 7.10 & 35 & 9.07 & 36 & 9.23 & 94 & 8.54 \\
\hline Aphids & 22 & 6.79 & 23 & 5.95 & 25 & 6.41 & 70 & 6.36 \\
\hline Planococcus sp. & 20 & 6.17 & 28 & 7.25 & 26 & 6.66 & 74 & 6.72 \\
\hline Collembola & 4 & 1.23 & 15 & 3.88 & 20 & 5.12 & 39 & 3.54 \\
\hline Total & 324 & - & 386 & - & 390 & - & 1100 & \\
\hline
\end{tabular}

* Number of insects collected in (8 samples $x$ 50 double strokes)

\subsection{Parasitoids:}

The survey revealed the occurrence of 17 hymenopterous parasitoid species, belonging to ten families (Table 3). Each of Braconidae and Trichogrammatidae was represented by three species. Two species were found belonging to each of Aphelinidae, Mymaridae and Scelionidae. Families: Bethylidae, Ceraphronidae, Encyrtidae, Eulophidae and Pteromalidae were each represented by only one species.

\subsection{Insect predators:}

Table (4) reveals the occurrence of 17 species of predatory insects, belonging to nine families and six orders. Four species belonged to Coccinellidae. Two species were found belonging to each of Carabidae. Staphylinidae, Mantidae, Syrphidae, Formicidae. One species belong to each of Anthocoridae, Reduviidae and Chrysopidae.

\subsection{Spiders (Order: Araneae):}

The spider species inhabiting Stevia fields are listed in Table (5). Sixteen spider species are belonging to 10 families (Order: Araneae). Araneidae and Linyphiidae were each represented by three species. The second rank of family occurrence was that of Lycosidae and Salticidae, as 
each represented by two species. Each of Dictynidae, Oonopiidae, Philodromidae, Pholcidae, Theridiidae and Thomisidae was represented by one species.

Table (3): Survey of hymenopterous parasitoids associated with Stevia insect pests at the Experimental Farm of Sakha Agricultural Research Station, during 2010/2011 and 2011/2012 seasons.

\begin{tabular}{|l|l|c|}
\hline \multicolumn{1}{|c|}{ Family } & \multicolumn{1}{|c|}{ Genera/species } & No. \\
\hline Aphelinidae & $\begin{array}{l}\text { Encarsia Formosa (Gahn) } \\
\text { Etremocerus mundus (Mercet) }\end{array}$ & 2 \\
\hline Bethylidae & Goniuzus sp. & 1 \\
\hline Braconidae & $\begin{array}{l}\text { Apanteles sp. } \\
\text { Bracon sp. } \\
\text { Cotesia sp. }\end{array}$ & 3 \\
\hline Ceraphronidae & Ceraphron sp. & 1 \\
\hline Encyrtidae & Mecroterus sp. & 1 \\
\hline Eulophidae & Tetrastichus sp. & 1 \\
\hline Mymaridae & $\begin{array}{l}\text { Anagrus atomus L. } \\
\text { Gonatocerus sp. }\end{array}$ & 2 \\
\hline Scelionidae & $\begin{array}{l}\text { Telonomus sp. } \\
\text { Trissolcus sp. }\end{array}$ & 3 \\
\hline Trichogrammatidae & $\begin{array}{l}\text { Trichogramma evanescens (Ashmead) } \\
\text { Oligosita sp. } \\
\text { Paracentrobia sp. }\end{array}$ & 1 \\
\hline Pteromalidae & Pteromalus sp. & 17 \\
\hline Total 10 & \multicolumn{1}{|c|}{17} & 2 \\
\hline
\end{tabular}

Table (4): Survey of predatory insects associated with Stevia insect pests at the experimental Farm of Sakha Agricultural Research Station, during 2010/2011 and 2011/2012 seasons.

\begin{tabular}{|c|c|c|c|}
\hline Order & Family & Genera/species & No. \\
\hline \multirow{3}{*}{ Coleoptera } & Carabidae & $\begin{array}{l}\text { Bemidian mixtum Schaum } \\
\text { Tachys sp. }\end{array}$ & 2 \\
\hline & Coccinellidae & $\begin{array}{l}\text { Coccinella undecimpunctata L. } \\
\text { Rhizobus litura Fab. } \\
\text { Scymnus interruptus Goeze } \\
\text { Stethorus gilviforns (Muls). }\end{array}$ & 4 \\
\hline & Staphylinidae & $\begin{array}{l}\text { Paederus alfierii (L.) } \\
\text { Philonthus sp. }\end{array}$ & 2 \\
\hline Dictyoptera & Mantidae & $\begin{array}{l}\text { Sphodromantis bioculata Sauss } \\
\text { Callidomantis savignyi L. }\end{array}$ & 2 \\
\hline Diptera & Syrphidae & $\begin{array}{l}\text { Syrphus corollae L. } \\
\text { Allogrpta sp. }\end{array}$ & 2 \\
\hline \multirow{2}{*}{ Hemiptera } & Anthocoridae & Orius livigtos L. & 1 \\
\hline & Reduviidae & Reduvius sp. & 1 \\
\hline Hymenoptera & Formicidae & $\begin{array}{l}\text { Solenopsis sp. } \\
\text { Monomorium sp. }\end{array}$ & 2 \\
\hline Neuroptera & Chrysopidae & Chrysoperla carnea Steph. & 1 \\
\hline Total 6 & 9 & 17 & 17 \\
\hline
\end{tabular}


Bazazo, K.G.I. et al.

Table (5): Survey of spiders, (Order: Araneae) associated with Stevia insect pests at the Experimental Farm of Sakha Agricultural Research Station during 2010/2011 and 2011/2012 seasons.

\begin{tabular}{|l|l|c|}
\hline \multicolumn{1}{|c|}{ Family } & \multicolumn{1}{|c|}{ Genera/species } & No. \\
\hline Araneidae & $\begin{array}{l}\text { Araneus sp. } \\
\text { Argiope trifasciata Forscal } \\
\text { Singa albobivittata Dicaporiacco }\end{array}$ & 3 \\
\hline Dictynidae & Dictyna sp. & 1 \\
\hline Linyphiidae & $\begin{array}{l}\text { Bathyphantes sp. } \\
\text { Erigone sp. } \\
\text { Lepthyphantes sp. }\end{array}$ & 3 \\
\hline Lycosidae & $\begin{array}{l}\text { Lycosa sp. } \\
\text { Pardosa sp. }\end{array}$ & 2 \\
\hline Oonopiidae & Unidentified & 1 \\
\hline Philodromidae & Thanatus albini (Audouin) & 1 \\
\hline Pholcidae & Pholcus phalangioides (Fuesslin) & 2 \\
\hline Salticidae & $\begin{array}{l}\text { Plexippus paykulli (Savigny) } \\
\text { Ballus sp. }\end{array}$ & 1 \\
\hline Theridiidae & Theridion sp. & 1 \\
\hline Thomisidae & Thomisius sp. & 16 \\
\hline Total 10 & & 16 \\
\hline
\end{tabular}

In the USA, Australia and China, spiders are effectively used in biocontrol programs. In China, particularly Hubei province, the use of chemical insecticides was reduced by $70-90 \%$ because of existing spiders in the fields (Rajeswaran et al., 2005).

Tables (3, 4 and 5) show that Stevia fields are rich in natural enemies; parasitoids, insect predators and spiders that should be conserved to keep the natural balance in the fields.

2.Identify arthropods (mainly insect pests) trapped in spider webs:

Web-weaver spiders trap their victims in the spun nets, and then, these victims become available prey to be fed upon.

The total numbers of arthropods collected in 180 webs of spiders were 92 individuals (Table 6), including insect pests, mites and even insect predators and parasitoids. The majority of collected arthropods were insect pests and mites (93.48\%). Fortunately, the insect predators and parasitoids constituted only 5.42 and $1.10 \%$, respectively of the total trapped arthropods. Most of trapped insect pests were Bemisia tabaci (16 nymphs and adults), followed by aphids (15 nymphs and adults), collembolan (13 nymphs and adults), Thrips tabaci (12 nymphs and adults) and Liriomyza trifolii (9 adults). Very few numbers of Tetranychus sp., Acrida sp., Solenopsis sp. and Anagrus were trapped in the webs ranging between one to five individuals. Nyffeler and Benz (1988) considered all arthropods found in webs of spider as prey, regardless if the spiders were observed feeding on them or not. 
Table (6): Arthropods trapped in webs of spiders; Araneidae, Dictynidae, Linyphiidae, Pholcidae and Theridiidae constructed on the soil and on Stevia foliage, during 2010/11 and $2011 / 12$ seasons.

\begin{tabular}{|c|c|c|c|}
\hline Taxa & Stage & No.* & $\%$ \\
\hline \multicolumn{4}{|l|}{ 1. Pests: } \\
\hline Bemisia tabaci & Nymph \& adult & 16 & 17.40 \\
\hline Cicadellidae & Nymph \& adult & 16 & 17.40 \\
\hline Aphids & Nymph \& adult & 15 & 16.30 \\
\hline Collembola & Nymph \& adult & 13 & 14.13 \\
\hline Thrips tabaci & Nymph \& adult & 12 & 13.04 \\
\hline Liriomyza trifolii & Adult & 9 & 9.80 \\
\hline Tetranychus sp. & Nymph \& adult & 3 & 3.30 \\
\hline Acrida sp. & Nymph & 2 & 2.17 \\
\hline Subtotal & & 86 & 93.48 \\
\hline \multicolumn{4}{|c|}{ 2. Insect predators and parasitoids } \\
\hline Solenopsis sp. & Adult & 5 & 5.42 \\
\hline Anagrus sp. & Adult & 1 & 1.10 \\
\hline Subtotal & & 6 & 6.52 \\
\hline Grand total & & 92 & \\
\hline
\end{tabular}

*Numbers of arthropods collected in 180 webs (12 samples $x 15$ webs).

\section{ACKNOWLEDGEMENT}

The authors wish to express their deep gratitude to Prof. Dr. Ramzy Sherif, Head of Entomology Department, Rice Research and Training Center, ARC for reviewing and valuable comments on the manuscript. Appreciation is also due to Prof. Dr. Ahmed S. Hendawy, Head of Research, Plant Protection Research Institute, for keen help in identifying the arthropod specimens. Also, thanks to Dr. Atta Hammad, Researcher (Agronomy), Sugar Crops Research Institute, for sincere help during the field experiments.

\section{REFERENCES}

Allam, A.I.; A.M. Nassar and S.Y. Besheit (2001). Nitrogen fertilizer requirements of Stevia rebaudiana Bertoni under Egyptian conditions. Egypt. J. Agric. Res., 79(3): 1005-1018.

Anonymous (2004). Stevia (0\% Calorie, 100\% Sweet, 100\% Nature). Science Tech., Entrepreneur, 12(10): $7 \mathrm{pp}$.

Anonymous (2010). Agronomy advancements and process optimization for increasing glycosides yield. Stevia cultivation workshop at $2^{\text {nd }}$ Stevia World Europe. Geneva, 18-19 May.

Anonymous (2010). Stevia Cooperative Extension Service, University of Kentucky, College of Agriculture.

Attia, A.E. (2005). Effect of some agronomic treatments on Stevia rebaudiana Bertoni, yield and quality in Egypt. Ph.D. Thesis, Agron Dept., Fac. Agric., Ain Shams Univ., Egypt.

Fors, A. (1995). A new character in the sweetener scenario. Sugar J. 58 (3). 


\section{Bazazo, K.G.I. et al.}

Heikal, A.H.; O.M. Badawy and A.M. Hafez (2008). Genetic relationship among some Stevia rebaudiana Bertoni. Accessions based on ISSR analysis. Research Journal of cell and Molecular Biology, 2(1): 1-5 pp.

Megeji, N.W.; J.K. Kumar; V. Singh; V.K. Kaul and P.S. Ahuja (2005). Introducing Stevia rebaudiana, a natural zero-calorie sweetener. Current Science, 88(5): 801-804.

Midmore, D. and A.H. Rank (2002). A new rural industry-Stevia- to replace imported chemical sweeteners. RIRDC web publication No. Wo2/022. RIRDE Project No. UCQ-16A.

Nassar, A.M.; S.M. Allam; A.I. Allam and S.Y. Besheit (2006). Effect of macronutrients (NPK) on productivity and quality of Stevia [Stevia rebaudiana) Bertoni] in Egypt. Egypt. J. Appl. Sci., 21(12-B): 463-481 pp.

Nyffeler, M. and G. Benz (1988). Prey and predatory importance of micryphantid spiders in winter wheat fields and hay meadows. Journal Applied Ent., 105: 190-197 pp.

Phillips, K.C. (1998). Stevia: Steps in developing a new sweetener: In T.H. Grenby ed. Developments in sweetener. Elsevier Applied, London.

Rajeswaran, J.; P. Durainurugan and P. Shanmugam (2005). Role of spiders in agriculture and horticulture ecosystem. Journal of Food, Agriculture and Environment, 3(3-4): 147-152 pp.

Tanaka, O. (1997). Improvement of taste of natural sweeteners. Pure. appl. Chem., 69: 675-683 pp.

Thomas, S.C. (2000). Medicinal plants-culture, utilization and phytopharmacology, technomic publishing co., Inc., Lancaster, Basel, p. 517

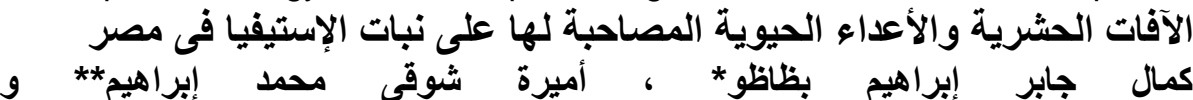

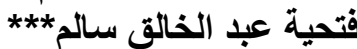

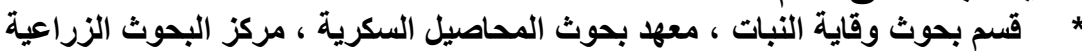

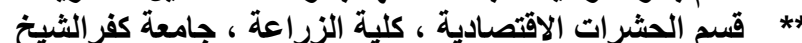

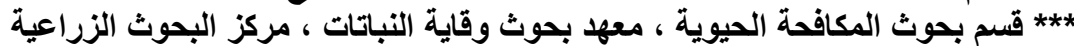

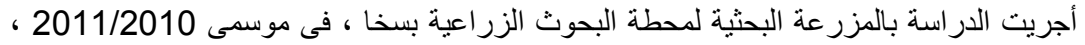

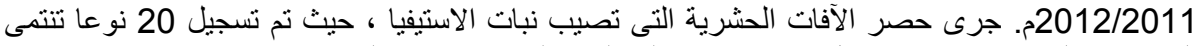

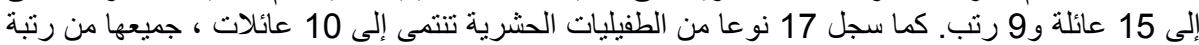

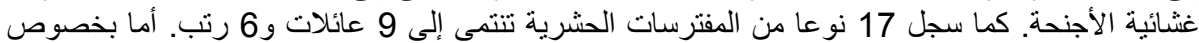

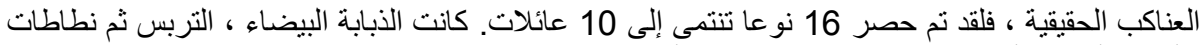

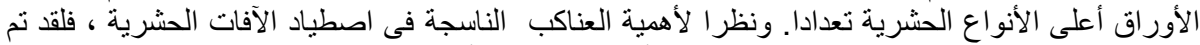

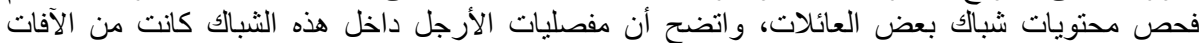

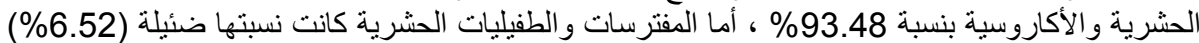

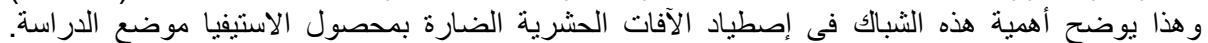

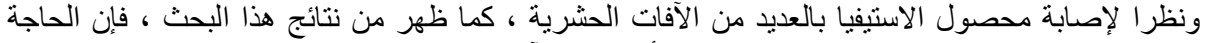

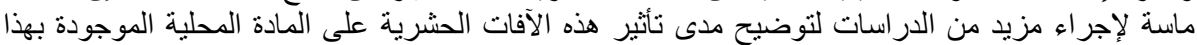

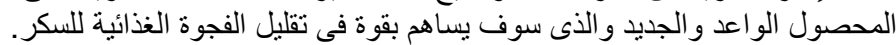

$$
\begin{aligned}
& \text { قام بتحكيم البحث البث } \\
& \text { كلية الزراعة - جامعة المنصورة }
\end{aligned}
$$

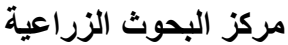

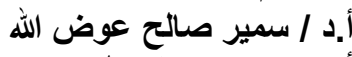

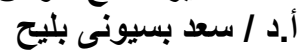


J. Plant Prot. and Path., Mansoura Univ., Vol. 3 (10), October, 2012 